Research, part of a Special Feature on Twenty Years of Community Forestry in Cameroon: Opportunities and Challenges for Sustainable Development

\title{
Community forest governance in Cameroon: a review
}

\author{
Serge Mandiefe Piabuo ${ }^{1}$, Divine Foundjem-Tita ${ }^{1}$ and Peter A. Minang ${ }^{1,2}$
}

\begin{abstract}
There is growing evidence that good community forest (CF) governance is a significant determinant of CF success. We examined the state of CF governance in Cameroon by applying a set of good governance principles to 36 case studies. Key good governance principles applied included accountability, equity, participation, representation, direction, and performance. The results revealed that the state of $\mathrm{CF}$ governance was relatively poor, with $78 \%$ of case studies not meeting standards for all the principles. Evidence suggests that all case studies did not meet standards for accountability and equity, while more than $70 \%$ of the case studies did not meet standards for participation, direction, and performance. Positive governance outcomes included increased CF employment; contribution to social investments like roofing of houses, provision of water, health, and training; improved community participation in sustainable management of forests; improved awareness of environmental protection and sustainable exploitation practices; and enabling fair representation of and empowerment of indigenous minorities such as the Baka, resulting in the creation of a Baka-led $\mathrm{CF}$. The presence of economic activities that generate direct benefits, the extent of technical support, and influential and supportive elites emerged as key drivers of positive outcomes in CF governance. These suggest that deploying incentives targeted at catalyzing enterprise development such as favorable loans, tax and financial support conditions, reinforced focused technical and institutional support including capacity building, and awards for supportive and innovative elites could go a long way to improve CF governance in Cameroon.
\end{abstract}

Key Words: community forest governance; inclusive resource management; livelihoods

\section{INTRODUCTION}

The concept of community forestry has evolved since publication of the seminal paper "Forestry for Local Community Development"(Food and Agriculture Organization of the United Nations [FAO] 1978). Researchers worldwide have underscored the importance of good governance as a critical condition to the success of community forestry in developing countries (Baynes et al. 2015). Governance, the process of decision making and implementation, becomes good when it is participatory, consensus oriented, accountable, transparent, responsive, effective, efficient, equitable, and inclusive and respects the rule of law (United Nations Economic and Social Commission for Asia and the Pacific [UNESCAP] 2006). Good governance at national through local levels reduces inequalities and encourages participatory decision making and sustainable management of forest resources (Dressler et al. 2010). On the other hand, poor governance reinforces rural poverty and promotes elite capture and poor management of resources. Principles of good governance have been developed to help evaluate and compare good practices while taking into consideration local realities of different countries.

We seek to assess community forestry-level governance in Cameroon. Community forest (CF) governance refers to the following: "Community level management and decision-making that is undertaken by, with, or on behalf of a community, by a group of community stakeholders. The focus on 'community' rather than on a corporation, organization, local government or the public sector is the distinguishing feature of community governance vis a vis $[s i c]$ other forms of governance" (Totikidis et al. 2005).

In Cameroon, CFs are defined by law as "that part of nonpermanent forest estate (not more than 5000 ha) that is the object of an agreement between government and a community in which communities undertake sustainable forest management for a period of 25 years renewable" (MINEF 1998:7). Community forestry emerged as part of a policy reform process aimed at enabling better participation of local people in forest management, enhancing the contribution of forests to livelihoods and the economy and enhancing sustainable forest management.

Two decades after the enactment of the concept of community forestry in Cameroon, there is still a heated debate about whether community forestry is an ideal strategy for sustainable forest management and poverty reduction (Karsenty and Vermeulen 2016, Tieguhong 2016). A review of the performance of CFs shows mixed results. Empirical studies in Cameroon show little or no change in the livelihoods of forest communities (Assembe 2006, Bigombé 2007). Poor governance features strongly among the many reasons cited for failures in community forestry so far (Brown and Lassoie 2010, Nkemnyi et al. 2016). Minang et al. (2007) identified access to financial services, poor knowledge and skills of management committees, and internal conflicts as major problems. The inefficiency of community forestry in Cameroon has been attributed to corruption, accountability, poor monitoring, and evaluation (Brown and Lassoie 2010, Alemagi 2011).

It is evident from these findings that good governance of CFs is imperative for effective community forestry. However, extensive literature focuses on the relationship between government and communities, whereas within-community governance literature is scarce. References to within-community governance in the literature remain patchy, appearing in few papers and reports and often tackling very specific aspects. These authors have also focused on the reasons and strategies to reduce negative outcomes of within-community governance without any verification of drivers of positive outcomes and how to scale-up. Hence, a somewhat comprehensive perspective on governance has been missing. In this regard, we attempt to fill this gap through a comprehensive review of current evidence on CF governance in 
Table 1. Modified common framework for assessing and monitoring forest governance.

\begin{tabular}{|c|c|}
\hline Principle & Aspects \\
\hline Participation: & $\begin{array}{l}\text { Involvement of citizens and stakeholders in decision making, either directly or through legitimate } \\
\text { intermediaries representing their interests. }\end{array}$ \\
\hline $\begin{array}{l}\text { Pillar 1: Policy, legal, institutional, } \\
\text { and regulatory frameworks }\end{array}$ & $\begin{array}{l}\text { Forest-related policies and laws; } \\
\text { Legal framework to support and protect land tenure, ownership, and use rights; } \\
\text { Concordance of broader development policies with forest policies; } \\
\text { Institutional frameworks; } \\
\text { Financial incentives, economic instruments, and benefit sharing. }\end{array}$ \\
\hline $\begin{array}{l}\text { Pillar 2: Planning and decision- } \\
\text { making processes }\end{array}$ & $\begin{array}{l}\text { Stakeholder participation and representation; } \\
\text { Transparency and accountability; } \\
\text { Stakeholder capacity and action. }\end{array}$ \\
\hline $\begin{array}{l}\text { Pillar 3: Implementation, } \\
\text { enforcement, and compliance }\end{array}$ & $\begin{array}{l}\text { Administration of forest resources; } \\
\text { Forest law enforcement; } \\
\text { Administration of land tenure and property rights; } \\
\text { Cooperation and coordination; } \\
\text { Measures to address corruption. }\end{array}$ \\
\hline Fairness/equity & $\begin{array}{l}\text { Equal opportunities for all members of community to improve or maintain their well-being, including } \\
\text { impartial application of rules. }\end{array}$ \\
\hline Accountability & $\begin{array}{l}\text { Responsibility of management committee to the community. } \\
\text { This relates to strategic vision: leaders and the public have a broad and long-term perspective on good }\end{array}$ \\
\hline Direction & governance and human development, along with a sense of what is needed for such development. \\
\hline Representation & The management committee is made up of men, women, and minority groups. \\
\hline Performance & $\begin{array}{l}\text { Institutions and processes should be responsive in trying to serve all stakeholders and should be effective and } \\
\text { efficient, producing results that meet needs while making the best use of resources. }\end{array}$ \\
\hline
\end{tabular}

Cameroon and an in-depth investigation of the drivers of positive outcomes and how efforts can be directed to improve $\mathrm{CF}$ governance. We seek to investigate the following: What are the key features of CF governance? How much evidence is available on the state of CF governance in Cameroon? What broad governance trends emerge from the evidence and with what prospects? What incentives can be deployed to enhance good governance?

\section{CONCEPTUAL FRAMEWORK}

Good governance principles constitute our conceptual framework. The principles of good governance were developed by UNESCAP (2006) and have been extensively used in the literature.

We will use a modified common framework for assessing and monitoring forest governance developed by the FAO and World Bank's Program on Forests (PROFOR) team of experts (PROFOR and FAO 2011). This framework has the potential to reduce overlapping assessment, monitoring, and reporting requirements and eliminate contradicting outcomes from previous initiatives. It can facilitate and channel efforts to improve assessment and monitoring of forest governance within and among countries and enhance the compatibility of different approaches (Maidell et al. 2012). This framework is based on the hypothesis that governance depends on the context and interaction of a range of stakeholders with diverse interests. It is built on three accepted pillars that represent the fundamentals of forest governance; the pillars are explained by 13 basic components (Table 1). The components under pillar 1 address clarity and consistency of these systems and their interrelation to define the context for forest decision making, forest use, and management. As for pillar 2, the components assess the degree of transparency, accountability, and inclusiveness of key forest governance processes and institutions. Moreover, it examines the characteristics of these processes and institutions, that is, the processes of key actors and how they account for the participation and representation of stakeholders and the accountability of power holders and decision makers. Pillar 3 investigates the level at which policy, legal, institutional, and regulatory frameworks are implemented. It further questions the degree of effectiveness, efficiency, and equitability of implementation. Table 1 shows the modified common framework for assessing and monitoring forest governance designed to fit the case of Cameroon and pillar 2 for within-community governance.

Some studies have examined some of these principles (Oyono and Efoua 2006, Tobith and Cuny 2006, Nkenfack et al. 2009, Monsi 2014, Ngang 2015), whereas others used UNESCAP's eight criteria of good governance to capture $\mathrm{CF}$ governance (Lamichhane and Parajuli 2014). In Cameroon, very few authors have evaluated more than two principles of good governance; participation, equity, and accountability were evaluated in the east region (Assembe 2006), and participation and equity were evaluated in the southwest region (Nkemnyi et al. 2016). Participation as an element was evaluated by many authors in different regions (Oyono and Efoua 2006, Tobith and Cuny 2006, Nkenfack et al. 2009, Monsi 2014, Ngang 2015). Accountability was equally investigated by many authors (Etoungou 2003, Oyono 2004, 2007, Maffo and Bokkestijn 2015), and equity was verified in some case studies (Oyono 2003, Ngang 2015). Forest conservation was verified in numerous case studies (Oyono 2005, Ezzine de Blas et al. 2009, Brown and Lassoie 2010, Beauchamp and Ingram 2011, Ngang 2015).

\section{METHODS}

Six principles of governance from the modified common framework for assessing and monitoring forest governance 
Table 2. Governance principle and indicators used in the study.

\begin{tabular}{|c|c|c|}
\hline Principle & Indicators & Outcome \\
\hline Participation & $\begin{array}{l}\text { Community members attend community forest }(\mathrm{CF}) \text {-related meetings regularly. } \\
\text { Participated in } \mathrm{CF} \text { activities. } \\
\text { Participated in training, study tours. } \\
\text { Freely contributed views at general assembly. } \\
\text { Poor/women/minority group voices considered while making decisions. }\end{array}$ & $\begin{array}{l}\text { Positive if evidence suggests the existence } \\
\text { of corresponding indicator. }\end{array}$ \\
\hline Accountability & $\begin{array}{l}\mathrm{CF} \text { management board accountable to all } \mathrm{CF} \text { members. } \\
\text { Rules for } \mathrm{CF} \text { general meeting and } \mathrm{CF} \text { board meetings. } \\
\mathrm{CF} \text { assembly guides } \mathrm{CF} \text { management. } \\
\text { Community updated on CF activities. } \\
\text { Easy access to information regarding decisions, fund, and so forth. }\end{array}$ & $\begin{array}{l}\text { Positive if evidence suggests the existence } \\
\text { of corresponding indicator. }\end{array}$ \\
\hline & Overall transparency. & $\begin{array}{l}\text { Positive if evidence suggests the existence } \\
\text { of corresponding indicator. }\end{array}$ \\
\hline Fairness/equity & $\begin{array}{l}\text { Specific schemes/provisions for poorest people. } \\
\text { Responsible in setting prices of forest products. } \\
\text { Satisfied with benefit-sharing system. } \\
\text { Representation of all social groups on CF management board according to rules } \\
\text { and regulations. }\end{array}$ & \\
\hline Representation & The management committee is made up of men, women, and minority groups. & $\begin{array}{l}\text { Positive if evidence suggests the existence } \\
\text { of corresponding indicator. }\end{array}$ \\
\hline Direction & $\begin{array}{l}\text { Use recommended measures to reduce overexploitation of forest products. } \\
\text { Have a long-term vision for forest conservation. } \\
\text { Respect the limits on the simple management plan. }\end{array}$ & $\begin{array}{l}\text { Positive if evidence suggests the existence } \\
\text { of corresponding indicator. }\end{array}$ \\
\hline Performance & $\begin{array}{l}\text { Improved livelihood of the community. } \\
\text { Investment in community projects. }\end{array}$ & $\begin{array}{l}\text { Positive if evidence suggests the existence } \\
\text { of corresponding indicator. }\end{array}$ \\
\hline
\end{tabular}

developed by the PROFOR and FAO team of experts were used (PROFOR and FAO 2011). Local indicators were developed, and the decision criterion for each indicator is shown in Table 2. Peerreviewed articles were obtained through Google Scholar research, and gray literature, reports, and nondigital publications were obtained from various sources. The first stage of the process was based on a review of all papers related to $\mathrm{CF}$ governance in Cameroon, a second screening selected those working on case studies, and in the last stage, 36 case studies were selected that investigated one or more principles of good governance used. Local governance indicators were selected based on good governance principles at the local level while taking into consideration the triple objectives of community forestry. These indicators seek to capture the composition of the management committee, decision-making mechanism, process and participation in $\mathrm{CF}$ activities, revenue generation, and use within the $\mathrm{CF}$. Interactive content analysis was used to determine the outcome, with special emphasis on directed analysis (Bakharia 2014). This method allows the quantification of communication patterns from texts of various formats. This permitted the researchers to classify outcomes as either positive or negative based on reported figures and impression of cited authors. Based on reported evidence, the researchers used local indicators to determine the outcome of a principle as illustrated in Table 2.

\section{RESULTS}

\section{Participation}

Inclusive participation requires the full participation of all members of the community in decision making and activities within the CF. Lack of community participation enhances illegal logging, deforestation, and disengagement of community members from CF activities (Assembe 2006, Oyono and Efoua
2006). Studies in Cameroon on participation and voice principally examined the inclusion of women and marginalized groups in decision making and $\mathrm{CF}$ activities. The composition of $\mathrm{CF}$ management committees and method of appointment were studied in the south region (Oyono and Efoua 2006). The authors revealed that only $10 \%$ of the management committee was democratically elected, and $20 \%$ took seats on the committee by consensus. They equally highlighted that $43 \%$ of members of the management committee were self-appointed. Elites or chiefs in villages often appoint themselves and their dependents. Elites who initiate and contribute significantly to the creation of the CF often decide among themselves to share the management positions; thus, democracy gradually disappears alongside participation.

In the east region, the participation of women in CF management was investigated (Tobith and Cuny 2006). During information meetings, women represented $35 \%$ of the population, and $30 \%$ during consultation meetings. They became absent in subsequent stages of the process. No woman was in attendance during constitution of the legal entity, data collection, drafting, and submission of the simple management plan (SMP). The Baka are a minority ethnic group living in the rain forest of Cameroon, northern Gabon, northern Republic of Congo, and southwestern Central African Republic; in Baka villages, tradition prevents women from taking up major positions on the board (Tobith and Cuny 2006). Women were sidelined from CF activities, and exploitation of nontimber forest products (NTFPs) was not commercial; women only acted as transporters of wood and thus did not benefit significantly from CF activities. This was principally because women believed timber exploitation was for men and thus saw no reason to take part in technical aspects of timber exploitation. 
Table 3. Participation and voice in community forests (CFs) in Cameroon.

\begin{tabular}{|c|c|c|c|}
\hline Authors & Year & Region & Major Outcome \\
\hline Oyono and Efoua & 2006 & South region & (-) Little or low participation of the community in decision making. \\
\hline Tobith and Cuny & 2006 & East region & $\begin{array}{l}(-) \text { Low participation of women after consultation meetings; Baka tradition } \\
\text { restricts women from sitting with men, thus preventing them from decision } \\
\text { making and participating in CF activities. }\end{array}$ \\
\hline Nkenfack et al. & 2009 & East region & $\begin{array}{l}(-) \text { The overall participation of women in the elaboration of the simple } \\
\text { management plan and training was low; they were sidelined from other CF } \\
\text { activities except transport of wood. }\end{array}$ \\
\hline Monsi & 2014 & Southwest region & $\begin{array}{l}\text { (-) Participation of community members in decision making and activities was } \\
\text { low; a few elites managed the affairs of the whole community. }\end{array}$ \\
\hline Ngang & 2015 & Southwest region & $\begin{array}{l}\text { (+) } 64 \% \text { of the population confirmed that community forestry has improved } \\
\text { community participation in forest management. }\end{array}$ \\
\hline Nkemnyi et al. & 2016 & Southwest region & $\begin{array}{l}\text { (-) Members of the community had little knowledge of the activities of the } \mathrm{CF} \text {, } \\
\text { and managers came from neighboring towns to manage the CF without } \\
\text { involving the community. }\end{array}$ \\
\hline
\end{tabular}

Investigating effective participation of women and minority groups, 200 individuals were surveyed in the east region (Nkenfack et al. 2009). The authors reported that women were essentially involved in the transportation of wood (30\%), because of limited skills and the physical nature of timber exploitation, whereas men worked as carriers $(70 \%)$, operators of chain saws, and mechanics. The participation of women in decision making in Lomié was greatly facilitated by nongovernmental organizations (NGOs) such as SNV Netherlands Development Organization and the World Wide Fund for Nature through their enlarged sensitization and training sessions. The overall participation of women was low; only $17.69 \%$ of the women were aware of an SMP, 18\% participated in preparatory meetings for the SMP, $6 \%$ participated in field work, and $4 \%$ participated in the drafting of the SMP. The participation rate of women in the training sessions was the lowest, only $3 \%$.

In the southwest region, the participation of managers in decision making in Bimbia-Bonadikombo CF was studied (Monsi 2014). From a sample of 41 respondents, $56 \%$ confirmed that they held a managerial position within the $\mathrm{CF}, 73 \%$ of this sample was only informed after decisions were made, while $20 \%$ was not informed and $7 \%$ remained neutral. Only $10 \%$ of the respondents were involved in project implementation, while $85 \%$ of respondents were not involved and the remaining $5 \%$ of respondents were neutral. We highlight a major governance problem in which community decisions are made by a few elites. This is because the few members who seem to have common interests make decisions that protect their interests and avoid opposition from other members.

Furthermore, 295 respondents were sampled to verify the level of community participation in Bakingili, Woteva, and BimbiaBonadikombo CFs (Ngang 2015). In all the three CFs, the respondents acknowledged that community forestry has improved the level of community participation in forest resource management. About $64 \%$ of the respondents accepted that community forestry has improved community participation, while $26 \%$ of respondents reported no improvement and $10 \%$ of respondents were neutral. This improvement is principally because of capacity improvement of the management committee members and community mobilization on the importance of taking part in meetings and $\mathrm{CF}$ activities.
Knowledge of local people about the existence of CFs was investigated in Tinto and Bimbia-Bonadikombo CFs (Nkemnyi et al. 2016). In Tinto CF, $90 \%$ of the population was aware of the existence of a $\mathrm{CF}$, while $10 \%$ had no clue of its existence. The purpose of the $\mathrm{CF}$ was not known to $73 \%$ of the population, while $27 \%$ who had knowledge of its purpose were mostly members of the $\mathrm{CF}$ management committee. The level of participation in the Bimbia-Bonadikombo $\mathrm{CF}$ was also low. Community members were aware of the existence of the $\mathrm{CF}$, but $60 \%$ had poor knowledge about the purpose and composition of the management committee of the CF. In both CFs, the community was not involved in the implementation of $\mathrm{CF}$ activities $(80 \%)$, while $60 \%$ did not take part in the decision-making process. The majority of the members of the committee of the BimbiaBonadikombo CF live in neighboring towns, and this accounts for poor management of the CF. Lack of knowledge about the importance of respecting regulatory policies regarding access to forest resources and corruption in obtaining licenses pushed many $\mathrm{CF}$ members to be sidelined from $\mathrm{CF}$ activities; thus, only enlightened elites who have the financial means and understand processes run $\mathrm{CF}$ activities. Table 3 shows the summary of the results.

\section{Accountability}

Accountability emanating from the democratic form of governance is twofold; it gives the right to be accounted to and to account to others (Oyono 2004). Accountability can be upward, that is, the accountability of the management committee to the forest administration; but this is not of significant interest to us because management committee members are obliged to and always meet this requirement. However, downward accountability, which refers to the management committee being accountable to the community, is of interest to us. The level of downward accountability was evaluated in Kompia CF (Etoungou 2003). The use of a general assembly to render accounts to the community was completely ignored in Kompia. Decisions were made by the chairman of the management board without consulting board members; he decided on microprojects for the community, and the benefit-sharing system was characterized by discrimination and favoritism. 
Table 4. Accountability of community forests in Cameroon.

\begin{tabular}{|c|c|c|c|}
\hline Authors & Year & Region & Major Outcome \\
\hline Etoungou & 2003 & Kompia (east region) & $\begin{array}{l}\text { (-) Decisions were made by the chairman, and he did not render accounts to } \\
\text { the people. }\end{array}$ \\
\hline Oyono & 2004 & Lomié (east region) & (-) Management committee did not render account to community. \\
\hline Assembe & 2006 & $\begin{array}{l}\text { Ngola and Moangue-le- } \\
\text { Bosquet (east region) }\end{array}$ & (-) No general assembly or access to accounts of the management committee. \\
\hline Oyono & 2007 & $\begin{array}{l}\text { Kongo (east region), } \\
\text { Mboké (south region) }\end{array}$ & $\begin{array}{l}\text { (-) No general assembly ever held to render accounts; community members } \\
\text { totally ignored. }\end{array}$ \\
\hline Maffo and Bokkestijn & 2015 & Southwest region & $\begin{array}{l}\text { (-) Very poor state of downward accountability; very few or no general } \\
\text { assembly held in some cases. }\end{array}$ \\
\hline
\end{tabular}

Source: Authors' compilation.

Local community members in the east region did not receive any statement from the management committee on the benefits from the sale of wood between the years 2000 and 2002 in the Lomie CF (Oyono 2004). Elites manipulated figures with the help of middle actors, i.e., administrative and council authorities, completely sidelining community members (Etoungou 2003). There is thus a major shift of interest from collective to individual profit-making interest. This lack of accountability by managers to the community led to total disorder in the $\mathrm{CF}$, with groups of households negotiating exploitation contracts with local timber companies; more than three contracts were signed for exploitation in one CF (Oyono 2004).

The Ngola and Moangue-le-Bosquet CFs never organized a general assembly since the creation of the CFs (Assembe 2006). Access to records was limited to members of the management committee; other community members were not allowed to consult accounts of the CF. The Baka were sidelined because no Baka were represented on the management committee. This was because management committee members believed they were accountable only to government officials and not to community members.

The existence of downward accountability was investigated in Kongo and Mboké CFs in the east and south regions, respectively (Oyono 2007). In the Kongo CF, a management committee called Comité de Gestion de la Forêt Communautaire de Kongo (COBANKO) was formed and legalized in 1998. COBANKO did not organize a general assembly between 1998 and 2007. The Mboké CF reflects the same organizational structure with no downward accountability, no general assembly, and no change of management committee. This is principally because members of the management committee work in their interest and not for the community; accounting for activities would only expose their woes.

Fourteen CFs in the south and east regions were studied (Maffo and Bokkestijn 2015). Respect of the governance norm of accountability, which stipulates that local community members be consulted on issues of community management, was investigated. Results reveal that in 7 of the $14 \mathrm{CFs}$, decisions were made by the management committee without consulting the population; the principles of equity and participation were violated in these CFs. Regulations demand that a general assembly meeting be held at least once a year to render account of activities within the CFs (Ministry of Forest and Fauna
[MINFOF] 2009). It was noted that 6 of the 14 CFs had never organized a general assembly meeting, $7 \mathrm{CFs}$ organized a general assembly meeting once over a period of 3 years, and only $1 \mathrm{CF}$ organized a general assembly meeting twice over a 3-year period. At the level of the management committee, decision making was not equitable; the management committee delegates made all decisions in $4 \mathrm{CFs}$, while $1 \mathrm{CF}$ organized 1 management committee meeting over 3 years, and 9 CFs organized 2 management board meetings over a period of 3 years. This shows relatively poor downward accountability (Oyono 2004). Table 4 summarizes the outcome for CF accountability in Cameroon.

\section{Equity}

Equity is fundamental for the success of community forestry. The 2009 manual of procedures published by MINFOF outlines that decision making and benefit sharing must be equitable among all social groups. The structure of decentralized management of forests was analyzed in 30 villages in the districts of Lomié, Dimako, and Mbang (east region) and Ebolowa and Kribi (south region; Oyono 2003). The management of revenue from the sale of timber was not accounted for in these villages. Funds meant for community development were often misappropriated by members of the management committee with complicity of subdivisional officers and officials from MINFOF (Oyono 2003). The local population was sidelined from the benefits of community forestry, a classic situation of misappropriation of funds and elite capture.

An evaluation of equity in the distribution of management positions in the management committee between youths and the old in the Kongo CF revealed that the youths think they have been sidelined by their parents and grandparents from local management of community organizations (Assembe 2004). They complain that the current management does not want to engage the youths and is not ready to follow a democratic process of designation of leaders or respect the mandate as stipulated in the constitution. This phenomenon has led to division of activities in the community; the old give orders, whereas youths act as laborers, leading to conflicts between youths and the old.

The benefit-sharing system of Ngola and Moangue-le-Bosquet CFs was also evaluated (Assembe 2006). These CFs generated 33.31 million Central African CFA francs (FCFA; USD 66,000) between 2001 and 2003 from timber exploitation. The management committee of the Ngola CF used the funds to buy and distribute 300 pieces of metal sheets for roofing of 45 houses, 
Table 5. Equity in community forest (CF) management.

\begin{tabular}{|c|c|c|c|}
\hline Authors & Year & Region & Major Outcome \\
\hline Oyono & 2003 & $\begin{array}{l}\text { Lomié, Dimako, Mbang (east } \\
\text { region); Ebolowa, Kribi (south } \\
\text { region) }\end{array}$ & (-) Local people sidelined from benefit sharing of revenue from CF exploitation. \\
\hline Assembe & 2004 & Kongo CF, east region & (-) Youths sidelined from management leading to verbal conflicts with the elderly. \\
\hline Assembe & 2006 & $\begin{array}{l}\text { Ngola and Moangue-le- } \\
\text { Bosquet } \\
\text { (east region) }\end{array}$ & (-) Revenue effectively shared, but minority groups highly discriminated against. \\
\hline Ngang & 2015 & $\begin{array}{l}\text { Bakingili, Bimbia- } \\
\text { Bonadikombo, Woteva } \\
\text { (southwest region) }\end{array}$ & $\begin{array}{l}\text { (-) No improvement in benefit-sharing system since the advent of community forestry; } \\
\text { high disparity in sharing benefits among social groups. }\end{array}$ \\
\hline Nkemnyi et al. & 2016 & $\begin{array}{l}\text { Tinto and Bimbia- } \\
\text { Bonadikombo (southwest } \\
\text { region) }\end{array}$ & $\begin{array}{l}\text { (-) Local population sidelined from decision making, exploitation of } \mathrm{CF} \text {, and benefit } \\
\text { sharing. }\end{array}$ \\
\hline
\end{tabular}

Source: Authors' compilation.

to build a house for the pastor of the Protestant church, to pay salaries, to buy food aid, and to buy a satellite dish and a community television set. Although the Bantu benefited from all these, only food aid and some soap were given to the Baka. Marginalization of the Baka was also manifested in the benefitsharing system of the Moangue-le-Bosquet CF.

Equity in the CF resource benefit-sharing system in Bakingili, Bimbia-Bonadikombo, and Woteva in the southwest region was also investigated (Ngang 2015). Results reveal that only $27 \%$ of the sample reported an improvement in forest resource benefit sharing, whereas $64 \%$ reported no improvement. As far as distribution of benefits among the different social groups was concerned, $84 \%$ reported that men benefited more than women, whereas $16 \%$ agreed that women benefited more than men. Disparity in terms of age was large; $78 \%$ confirmed that older people benefited more than the young, whereas $19 \%$ thought otherwise. Disparity between indigenous and nonindigenous people was also present; $43 \%$ reported that the benefit-sharing system favored indigenous people, whereas $57 \%$ of the population thought otherwise. There was a significant disparity in the equity of the community resource benefit-sharing system among the three CFs studied. More than half of the sample $(54 \%)$ that revealed no improvement in benefit-sharing system came from Bimbia-Bonadikombo, while 38\% came from Bakingili and only $4 \%$ from Woteva. The low rate of improvement in the BimbiaBonadikombo $\mathrm{CF}$ was principally because of instances of corruption, embezzlement, and "elite capture" of the CF. Woteva, however, shows that when a proper governance system exists, the community can benefit substantially from community forestry.

In the same light, the benefit-sharing system in the Tinto and Bimbia-Bonadikombo CFs was investigated (Nkemnyi et al. 2016). Exploitation of the CFs for commercial purposes was limited to influential elites or those who had the financial means to buy their way through. Both CFs had been commercially exploiting timber for 10 years, but evidence of social facilities was absent, and no records existed on developmental activities financed with funds from the CFs. Table 5 shows a summary of equity outcomes from CFs in Cameroon.

\section{Direction and vision in community forest management}

Sustainable exploitation of natural resources remains one of the principal motivations for devolution of power to local communities. The advent of community forestry in Bakingili, Woteva, and Bimbia-Bonadikombo has improved awareness of the local population about environmental protection (Ngang 2015). Bakingili and Bimbia-Bonadikombo reported the highest levels of awareness, $43 \%$ and $38 \%$, respectively, with only $19 \%$ for Woteva CF. The adoption of agroforestry practices (71\%), cut and replant $(41 \%)$, and selective hunting (38\%) are among sustainable harvesting measures used in the three CFs studied. With the advent of community forestry, afforestation and reforestation have been introduced and practiced as a medium to maintain the forest for long-term exploitation. Evidence reveals that $63 \%$ of the respondents confirm that afforestation and reforestation have been carried out in the communities with the devolution of power to local communities. This is principally because of technical support and training from local NGOs and conservation societies in the southwest region.

Sustainability of community forestry was evaluated in 30 villages in the districts of Ebolowa and Kribi (south region), as well as Lomié, Dimako, and Mbang (east region) by Oyono (2005). Industrial logging is forbidden in CFs; small-scale exploitation is encouraged because of its ecological benefits (MINFOF 2009). Many villages in the south region contract big logging companies to exploit CFs leading to overexploitation of the forest above the provisions of the SMP. In Mboké CF, industrial logging of trees has led to destruction of flora by opening paths in the forest during transportation of wood.

In the southwest region, illegal exploitation dominates within the five villages that make up the $\mathrm{CF}$; there are at least 10 illegal exploiters per village (Kombo, Epiemele, and Oyono, unpublished manuscript). Illegal overexploitation of Prunus africana bark for sale to a pharmaceutical company called Plantecam by locals has accelerated the extinction of this tree species.

Using the same methodology, 20 CFs were studied in Cameroon in the lowland humid forests and mountain forests (Ezzine de Blas et al. 2009). The results highlight that the quest for short-term gains leads to illegal and unsustainable industrial exploitation of CFs. This is very severe with timber exploitation in the south and 
Table 6. Community forest (CF) direction and vision in $\mathrm{CF}$ management in Cameroon.

\begin{tabular}{|c|c|c|c|}
\hline Authors & Year & Region & Major Outcome \\
\hline Oyono & 2005 & $\begin{array}{l}\text { Lomié, Dimako, Mbang (east } \\
\text { region); Ebolowa, Kribi (south } \\
\text { region) }\end{array}$ & (-) Industrial exploitation of CFs and overexploitation of resources. \\
\hline $\begin{array}{l}\text { Ezzine de Blas et } \\
\text { al. }\end{array}$ & 2009 & $\begin{array}{l}\text { Southwest, south, east, center, } \\
\text { and northwest regions }\end{array}$ & (-) Unsustainable industrial logging in CFs. \\
\hline Brown and Lassoie & 2010 & Center and east regions & $\begin{array}{l}(-) \text { Industrial logging and nonrespect of logging rotations and logging beyond CF } \\
\text { borders. }\end{array}$ \\
\hline $\begin{array}{l}\text { Beauchamp and } \\
\text { Ingram }\end{array}$ & 2011 & $\begin{array}{l}\text { Communauté Villageoise de } \\
\text { Melombo, Okekat et Faekele } \\
\text { (COVIMOF) and Common } \\
\text { Initiative Group (GIC) Doh } \\
\text { (east region) }\end{array}$ & $\begin{array}{l}\text { (-) Aggravated and illegal industrial exploitation of timber; unplanned and } \\
\text { undemarcated land use system. }\end{array}$ \\
\hline Ngang & 2015 & $\begin{array}{l}\text { Bakingili, Woteva, and } \\
\text { Bimbia-Bonadikombo } \\
\text { (southwest region) }\end{array}$ & $\begin{array}{l}\text { (+) Improved awareness in environmental protection and practice of sustainable } \\
\text { exploitation practices. }\end{array}$ \\
\hline
\end{tabular}

east regions where communities do not sustainably manage their forests and prefer present economic gains over long-term benefits of forests.

Ecological health of community forestry is an important indicator of sustainability; the ecological outcomes of community forestry in nine villages in the center and east regions were examined (Brown and Lassoie 2010). Industrial logging and transport of logs for transformation outside the forest opens paths within the forest and destroys flora. Though legally banned, it is extensively practiced. Communities often prefer to contract industrial logging companies instead of the recommended artisanal logging. Only one of the nine villages practiced artisanal logging. Absence of direction and vision for the CF is often manifested through nonrespect of logging rotations and logging beyond $\mathrm{CF}$ borders (Ezzine de Blas et al. 2009).

Environmental sustainability of community forestry was investigated in two CFs (Common Initiative Group [GIC] Doh and Communauté Villageoise de Melombo, Okekat et Faekele [COVIMOF]) in the east region (Beauchamp and Ingram 2011). These authors noticed that the high environmental cost of COVIMOF was because of past exploitation patterns characterized by unplanned and undemarcated land use change. This was principally because of aggravated and illegal industrial exploitation of timber. Contrary to COVIMOF, GIC Doh had a defined agricultural area that set limits of expansion of smallholder agriculture. This reduced the incidence of encroachments and illegal clearance for agriculture, thus encouraging sustainable exploitation of natural resources. Table 6 shows a summary of direction and vision in CF management in Cameroon.

\section{Representation}

An evaluation of the representation of minority groups in the management committee of Ngola CF revealed that the management committee did not have any representatives of the Baka minority (Assembe 2006). The Baka were thus not informed of management activities in the $\mathrm{CF}$ or implementation processes. It is difficult to tell whether this was deliberate or by chance. The Baka were only involved in transportation of timber from the forest to the road.
The representation of the Baka in the management committee of the Moangue CF was also evaluated; however, the Baka were fairly represented in the management committee, although they were not democratically elected (Assembe 2006). Appointment was done vertically by the "Dutch technical assistance" project team and local territorial forest administration. This was because the Baka made up most of this community and were enlightened because of regular technical support from NGOs.

The representation of women in management committees was evaluated through interviews and field questionnaires with 16 NGOs and corresponding communities they support (Tobith and Cuny 2006). The findings revealed that women were often present in consultation and information meetings during the creation of the $\mathrm{CF}$; however, during election of the management committee, they were often removed from the list, even when they applied to be candidates. On average, only $18 \%$ of the management committee members were women. The tradition of women not having the right of ownership to land was one of the principal reasons for being sidelined. In the Moangue-le-Bosquet $\mathrm{CF}$, a woman was elected as vice president of the $\mathrm{CF}$, but because of pressure from men and tradition, she was forced to step down. Because timber exploitation was the most dominant activity in the $\mathrm{CF}$, most women did not find it interesting.

An evaluation of the representation and participation of women in sustainable management of Bimbia-Bonadikombo $\mathrm{CF}$ revealed that women were not adequately represented in the management committee of the CF, accounting for less than $10 \%$ (Fondufe et al. 2016). This low representation of women was because of the tradition and culture of the people, which did not consider women at the same level as men to make decisions. Table 7 shows a summary of CF representation in Cameroon.

\section{Performance}

The environmental and economic performance of CFs reflects the well-being of the local population and community capacity in natural resource management. The economic performance of $\mathrm{CFs}$ is reflected through equitable implementation of microprojects. Studies from Mboké CF show that only $12 \%$ of revenue from timber exploitation was used for construction of a 
Table 7. Community forest (CF) representation in Cameroon.

\begin{tabular}{llll}
\hline \hline Authors & Year & Region & Major Outcome \\
\hline Tobith and Cuny & 2006 & $\begin{array}{l}\text { Center, south, northwest, east, } \\
\text { littoral }\end{array}$ & $\begin{array}{l}\text { (-) On average, only 18\% of management committee members were women, } \\
\text { and they hardly held key positions. } \\
(-) \text { Low or zero representation of minority groups in management committee } \\
\text { of Ngola CF. } \\
\text { Assembe }\end{array}$ \\
$\begin{array}{llll}\text { Assembe } \\
\text { Fondufe et al. }\end{array}$ & 2006 & $\begin{array}{l}\text { Moangue CF, east region } \\
\text { Bimbia-Bonadikombo (southwest } \\
\text { region) }\end{array}$ & $\begin{array}{l}\text { (-) Women occupied less than 10\% of management seats and were } \\
\text { marginalized because of strict tradition. }\end{array}$ \\
\hline
\end{tabular}

Source: Authors' compilation.

classroom, implying that the management committee did not account for the remaining $88 \%$. In Kongo village, 30 houses were roofed with metal sheets in 2002 (Oyono 2003).

The contribution to community forestry in the development of social infrastructure was evaluated in the Gbopaba CF (east Cameroon; Mbile et al. 2009). The results revealed that from a total revenue of 34 million FCFA, 22 million FCFA was invested in roofing materials for homes and churches, training, health, water supply maintenance, and student fees. This is a classic example of a situation where community forestry has contributed to the social well-being of the local population.

Community well-being in terms of assets and social benefits remains poor in Monkoualiyé and Mpewang CFs in the east region (Eloundou 2012). Community projects such as construction of water points, a health center, a nursery school, and a public shed were outlined in the SMP of Monkoualiyé. A sum of 5.3 million FCFA was generated from timber exploitation in 2008; $64 \%$ of this amount was used to pay debts of partners who prefinanced the expenditure linked to exploitation, and the remaining $36 \%$ was spent on salaries for personnel and compensation for destruction of farms during exploitation. The community did not benefit at all from CF exploitation activities. By the end of the year, the CF did not have enough funds to finance exploitation for the next year; thus, this phenomenon will continue if everything remains the same. The situation in the Mpewang CF was similar; revenue from exploitation was spent on scholarships to students, other didactic materials, payment of salaries, and compensation to farmers whose farms were destroyed during exploitation. No social infrastructure existed after 3 years of exploitation (2005-2008). Mpemog CF faced the same situation.

Access to social services was investigated using "access to school," "community capacity," "health services," and "NGO presence" to capture community well-being facilities in four sites in Cameroon (Oyono et al. 2012). Overall results showed no improvement in "access to school" and "health services," whereas the presence of NGOs increased in all four study sites and local capacity increased in Lomié/Dja and the Mount Cameroon area. With the devolution of management power to local communities, actions to maintain the resource base remained poor in the four study sites.

The cost and benefits of community forestry in Cameroon were investigated by Ingram et al. (2010) using a sample covering five regions of Cameroon. A comparative analysis between the $\mathrm{CF}$ scenario and the no-CF scenario was carried out. Their results revealed that $66 \%$ of the CFs studied were slightly economically and environmentally profitable compared with the no-CF scenario. The economic benefit of community forestry was evaluated in two strands: timber and NTFPs. Economic benefits from timber exploitation for the $\mathrm{CF}$ scenario stand at 31 million FCFA, whereas benefits from the no-CF scenario stand at 6 million FCFA. No major difference was noticed between the two scenarios for (NTFPs) exploitation. The contribution of community forestry to biodiversity was evaluated using biodiversity values for carbon, soil fertility loss, and groundwater production; the CF scenario registered 10.9 million FCFA compared with 9.1 million FCFA for the no-CF scenario.

The economic, social, and environmental benefits of community forestry were evaluated in the Woteva, Bakingili, and BimbiaBonadikombo CFs (Ngang 2015). The results revealed no significant change in CF income, employment, and infrastructure; thus, community forestry did not improve economic benefits, which confirmed the findings of empirical research (Minang et al. 2007, Mbile et al. 2009, Oyono et al. 2012). However, the low level of community employment was in contrast with other studies that have confirmed the creation of youth employment opportunities through timber exploitation (Cuny et al. 2007). This means that economic benefits will likely accrue for $\mathrm{CF}$ s with active operations. Forest cover equally increased with the advent of the CF within all three CFs involved (Ngang 2015), although that of Bimbia-Bonadikombo was not significant. Wildlife protection, environmental awareness, sustainable exploitation practices, and forest regeneration techniques have simultaneously improved with the advent of community forestry. Conservation and patrols contributed to improvement of forest cover, while training sessions from civil society groups have improved awareness of forest management within these communities.

Respect of the principle that demands CFs invest $90 \%$ of their income in community projects was investigated in $14 \mathrm{CFs}$ in the south and east regions (Maffo and Bokkestijn 2015). Their results reveal that no $\mathrm{CF}$ respects the prescription of $90 \%$ revenue to be committed for the realization of community projects. Only $1 \mathrm{CF}$ used up to $75 \%$ of its revenue on community projects, which is 3 times the national average of $25 \%$ (Cuny 2011). Contracts with dubious contractors, high administrative costs, poor internal governance, and lack of transparency in $\mathrm{CF}$ income management are pertinent reasons for poor implementation and dedication of funds to community projects.

An evaluation of the monetary and nonmonetary benefits of the Bimbia-Bonadikombo $\mathrm{CF}$ revealed that income from forest 
Table 8. Community forest (CF) performance in Cameroon.

\begin{tabular}{|c|c|c|c|}
\hline Authors & Year & Region & Major Outcome \\
\hline Oyono & 2003 & Ngola, Kongo, and Mboké (east region) & $\begin{array}{l}\text { (-) Only } 12 \% \text { of revenue from timber exploitation was used for construction } \\
\text { of a classroom. }\end{array}$ \\
\hline Etoungou & 2003 & Moangue-le-Bosquet $\mathrm{CF}$, east region & $\begin{array}{l}\text { (+) Empowerment of local communities led to the creation of a CF by the } \\
\text { Pygmy. }\end{array}$ \\
\hline Oyono & 2005 & $\begin{array}{l}\text { Lomié, Dimako, Mbang (east region); } \\
\text { Ebolowa, Kribi (south region) }\end{array}$ & $\begin{array}{l}(-) \text { Although minor community projects were executed, they were very } \\
\text { minimal compared with revenue. }\end{array}$ \\
\hline Cuny et al. & 2007 & Kongo $\mathrm{CF}$ in the east region & (+) CF employment increased because of timber exploitation. \\
\hline Mbile et al. & 2009 & Gbopaba CF (east Cameroon) & $\begin{array}{l}(+) \text { Contribution to social investment like roofing for housing, provision of } \\
\text { water, health, and training. }\end{array}$ \\
\hline Ingram et al. & 2010 & $\begin{array}{l}\text { Southwest, south, east, center, and littoral } \\
\text { regions }\end{array}$ & $\begin{array}{l}\text { (+) } 66 \% \text { of CFs studied were slightly better off than no-CF scenario } \\
\text { ecologically and economically. }\end{array}$ \\
\hline Eloundou & 2012 & Monkoualiyé and Mpewang (east region) & $\begin{array}{l}(-) \text { The community did not benefit at all from exploitation activity in the } \\
\text { CF. }\end{array}$ \\
\hline Oyono et al. & 2012 & $\begin{array}{l}\text { Lomié/Dja (east region), Mount Cameroon } \\
\text { area (southwest region), ocean area (south } \\
\text { region), and Mount Oku area (northwest } \\
\text { region) }\end{array}$ & $\begin{array}{l}\text { (-) Overall results showed no improvement in "access to school" and } \\
\text { "health services"; actions to maintain the resource base remained poor in } \\
\text { the four study sites. }\end{array}$ \\
\hline Ngang & 2015 & $\begin{array}{l}\text { Bimbia-Bonadikombo, Woteva, and } \\
\text { Bakingili CF in the southwest region }\end{array}$ & $\begin{array}{l}(+) \text { Improvement in knowledge of forest conservation and forest cover } \\
\text { within the three CFs. }\end{array}$ \\
\hline Nuesiri & 2016 & $\begin{array}{l}\text { Bimbia-Bonadikombo } \mathrm{CF} \text { (southwest } \\
\text { region) }\end{array}$ & $\begin{array}{l}\text { (-) Income from forest exploitation was used essentially to pay workers and } \\
\text { fund operational costs; nothing was used to fund community projects. }\end{array}$ \\
\hline $\begin{array}{l}\text { Maffo and } \\
\text { Bokkestijn }\end{array}$ & 2015 & South and east regions & $\begin{array}{l}\text { (-) Only } 1 \mathrm{CF} \text { uses } 75 \% \text { of its revenue on community projects (construction } \\
\text { of } 2 \text { classrooms and an administrative unit). }\end{array}$ \\
\hline
\end{tabular}

Source: Authors' compilation.

exploitation was used to pay workers and fund operations; nothing went to fund community projects (Nuesiri 2016). This discouraged elites from activities of community forestry, but local people were still engaged because of lack of alternatives. Table 8 summarizes $\mathrm{CF}$ performance in Cameroon.

\section{DISCUSSION}

\section{Toward incentivizing good governance outcomes}

We confirm the poor state of governance in the CF subsector in Cameroon through a useful compilation and analysis. With 78\% of our case studies reporting negative outcomes, we focus on learning from the few positive governance outcomes from the review, because these have generally been rare, in a bid to suggest incentive approaches to good governance in community forestry. Understanding the drivers of positive outcomes that we have recorded would be helpful in identifying potential incentives for good governance. Table 9 and Figure 1 clearly show the few positive outcome instances recorded and how these are distributed among the 36 cases studied. In terms of good governance principles, 5 of the positive outcomes are under the performance principle, while 1 each is recorded for participation, representation, and direction. Figure 1 suggests 2 geographic clusters of outcome occurrence: 1 in the southwest region and another in the east region, perhaps indicating a possible role for contextual factors in determining good governance outcomes.

The compilation in Table 10 highlights technical and financial support, community mobilization, and participation as principal drivers of positive outcomes. This result falls in line with the findings of Duguma et al. (2018) that identified priority enablers to improve the performance of CFs in Cameroon by applying content analysis to 41 publications. Benefit generation, partnership, monitoring, policy support, and technical support came up as the top 5 variables. These were followed by financial support, practices, institutional factors, and governance. It is important to note that strong associations and dependencies were observed between these factors.

The drivers also converge with findings from an extensive review of key factors of success in developing countries (Baynes et al. 2015). They highlight that intra-CF governance can directly be improved through social cohesion, capacity building, and participation of all social groups. Social cohesion, which is a significant determinant of CF good governance, depends on socioeconomic and gender equality and capacity building. Tree and tenure rights give $\mathrm{CF}$ members harvest rights through devolution. This opens the way to access rights; when $\mathrm{CF}$ members effectively enjoy these rights, they are motivated to participate in $\mathrm{CF}$ decision-making processes and activities, thus improving CF governance. Capacity building, i.e., managerial and sustainable forest exploitation, has been highlighted as a significant contributor to intra-CF governance (Baynes et al. 2015). This often comes through projects aimed at promoting community forestry and government support programs. We briefly discuss each of the drivers of positive outcomes subsequently and identify potential incentives for eliciting more of such positive outcomes.

\section{What incentives for enhancing drivers of positive outcomes in Cameroon?}

Incentives have emerged as a strategic mechanism for scaling-up positive outcomes in natural resource management and for $\mathrm{CF}$ governance (Sitoe and Guedes 2015, Minang 2018). Incentives mean "anything that can motivate an agent to take a particular course of action" or "any policy, program, institution or economic instrument that motivates conservation and management of forest ecosystems" (Casey et al. 2006:19). They can be broadly 
Table 9. Summary of community forest governance outcomes from this study.

\begin{tabular}{lcccc}
\hline \hline Governance Principle & $\begin{array}{c}\text { Number of Case } \\
\text { Studies }\end{array}$ & $\begin{array}{c}\text { Number of Case } \\
\text { Studies with Positive } \\
\text { Outcomes }\end{array}$ & $\begin{array}{c}\text { Number of Case Studies with } \\
\text { Negative Outcomes }\end{array}$ & $\begin{array}{c}\text { Percent of Positive } \\
\text { Outcomes }\end{array}$ \\
\hline Participation and voice & 6 & 1 & 5 & 17 \\
Accountability & 5 & 0 & 5 & 0 \\
Equity & 5 & 0 & 5 & 0 \\
Direction & 5 & 1 & 3 & 20 \\
Representation & 4 & 5 & 6 & 25 \\
Performance & 11 & 8 & 28 & 22 \\
Total & 36 & & & 25 \\
\hline
\end{tabular}

Source: Authors' compilation.

given as fiscal, e.g., taxes, tariffs, and subsidies; economic, e.g., low-interest loans, compensation for certain investments, conditional payments, or premiums; reputational, e.g., name and shame, as well as awards; and administrative, e.g., privileged access, land/tree rights, and shorter processing times, incentives. Emerging literature discusses five categories of incentives, namely, involuntary regulatory disincentives; voluntary; nonregulatory economic; institutional innovations that provide market, legal, and planning authorities to enhance resource conservation; and facilitative incentives including administrative and technical assistance (Heimlich et al. 1998). These incentives can have a significant positive impact on $\mathrm{CF}$ dynamics and related governance outcomes.

\section{Income and direct benefits from community forest activities}

The desire to participate in CF decision-making processes and activities in an equitable manner with good accountability to realize community projects and sustainably manage natural resources depends on the availability of income-generating activities. Community devotion and engagement reduces when participation in CF activities does not contribute to individual or community benefits. Low levels of participation can be explained by lack of income-generating activities in the community; thus, only a few committee members attend meetings and make decisions. Supporting evidence of these findings highlights that provision of early and continuous benefits is critical to organizational cohesion; otherwise members will leave (Calderon and Nawir 2006). However, when economic activities are ongoing, community members are ready to sacrifice their private activities to attend meetings, participate in activities, and monitor the management to be sure funds are effectively managed. Involvement and success in community forestry require that the communities be actively engaged in income-generating activities.

\section{Incentives}

To enhance development of economic activities and generation of benefits associated with community forestry, enterprise stimulation incentives might be needed. This could range from tax breaks, soft loans, and cost sharing for the acquisition of capital expenditure items to value chain development activities such as ecolabeling, enhancing prices and value of products, and opening markets for biodiversity and carbon. These incentives have been deployed in Cameroon and elsewhere in the context of community forestry. For example, the partnership for the development of CFs, a project funded by the Congo Basin Forest Fund (2010-2013), provided capacity building, technical, and financial assistance to three $\mathrm{CF}$ groupings in the center and east regions of Cameroon to develop autonomous CFs. The Dryad Project is currently providing public finance to $\mathrm{CFs}$ in a bid to develop viable community forest enterprises (CFEs). Between 2007 and 2010, the World Wide Fund for Nature ran the Community-Based Forest Enterprises Project in Cameroon, supporting CFs in the southeast and southwest of Cameroon to develop sustainable forestry techniques and business management skills in a bid to create CFEs (Bakouma and Sève 2012).

\section{Technical support}

The advent of community forestry has contributed significantly to the development of local knowledge on sustainable management of natural resources, thanks to support from the civil society. NGOs play a significant role in building local capacity in sustainable management of natural resources in the southwest region (Ngang 2015). Harvesting techniques of NTFPs have improved significantly with the advent of community forestry (Eben 2014). Empowerment of the Baka has resulted in the creation of the Moangue-le-Bosquet CF in the east region, and continuing efforts from the civil society have significantly contributed to sustainable harvesting and exploitation of natural resources (Etoungou 2003). The development and improved livelihood impacts of community forestry in Kongo are largely because of local and international NGO support. Assistance ranged from conflict resolution, capacity building on forest regeneration, and enrichment planting to performance evaluation and understanding regulations regarding sustainable forest management. The CFs were assisted on how to develop incomegenerating activities such as creating a special management plan on priority NTFPs with special emphasis on commercialization and value addition (Etoungou 2003). Valorization of other products like charcoal, honey, and firewood contributed significantly to development of local entrepreneurial knowledge and sustainable CF management. Technical assistance has been instrumental in managing conflicts in CFs and putting in place conflict management mechanisms that have facilitated community management and conflict resolution. The inclusion of conflict management teams in articles of association of recently created CFs is a pertinent example.

\section{Incentives}

"Sermon" ${ }^{[1]}$ type incentives such as capacity development and institutional support and specialized training that targets specific needs can reinforce technical support. There is evidence that 
Fig. 1. Distribution of community forest (CF) governance outcomes from case studies in Cameroon.

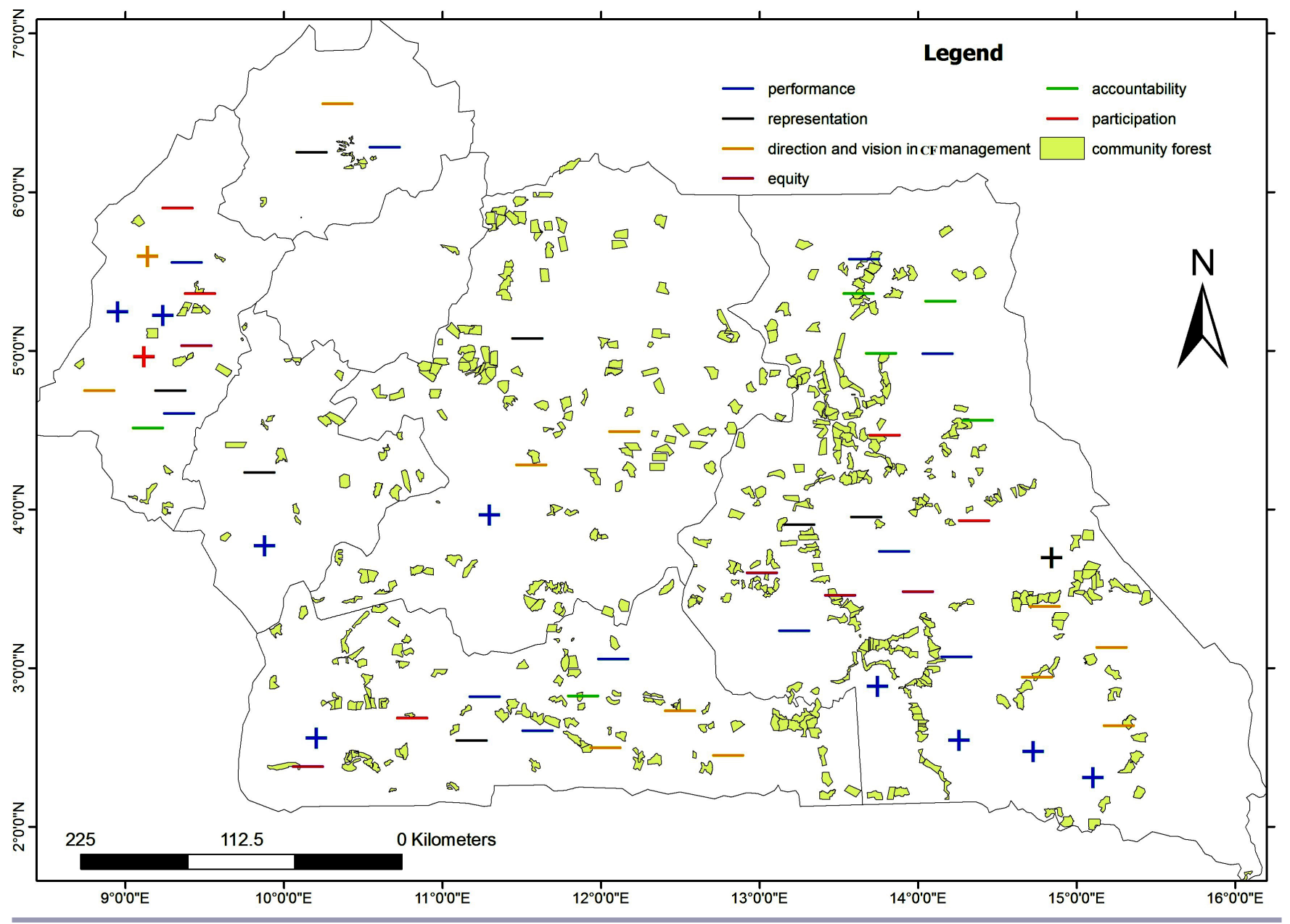

massive technical support and training from civil society were crucial in the development of community forestry in Cameroon in the past (Duguma et al. 2018; Minang, Duguma, Bernard, et al., unpublished manuscript). This might require concerted effort across a couple of government departments that have traditionally not intervened in community forestry. For example, the Ministry of Finance (MINFI) and Ministry of Small and Medium-Size Enterprises, Social Economy and Handicrafts (MINPMESSA) can help provide technical and financial support and training in a bid to help CFs develop. These agencies would obviously work hand in hand with the incentives suggested herein on enterprise in terms of providing the necessary training and support.

\section{Elites: a double-edged sword}

Elites can be initiators of positive outcomes and can also be propagators of negative outcomes. The presence of enlightened elites with significant interest in community development, also known as "positive elites," helps propel communities to realize their objectives. When these leaders mobilize the community, create partnerships, and invest revenue in community infrastructure (Bodin and Crona 2008), these positive elites have been drivers of positive outcomes for many communities. This is especially true for some communities with chiefs as president or delegates in the CF management committee. They are often respected, and community members are often devoted to work with their chief. The influence of positive elites in the east region has contributed significantly to community development in the area (Cuny et al. 2007). This can be explained by the fact that these communities are often small and can easily collaborate. The integration of customary tradition in CF management can propel elites to be more engaged and accountable; traditional sociocultural traits with integration of core values of the local people coupled with moral and political legitimacy can be more stable and enduring (Kayambazinthu et al. 2003).

Incentives

In whatever directions the elites steer $\mathrm{CF}$ governance, it might be helpful to conceive and implement incentives such as awards for rewarding good behavior and positive outcomes and disincentives such as naming and shaming and punishment or prosecutions in cases of bad behavior, for example, corruption, embezzlement, and power abuse by elites. The community forestry network and the subdirectorate of community forestry in MINFOF could institute recognition and an award-type approach to CFs on a periodic basis, in which the elites that support and are 
Table 10. Key drivers of positive outcomes from specific case studies.

\begin{tabular}{|c|c|c|}
\hline Positive Outcome & Community Forest (CF) & Suggested Key Factor Description \\
\hline $\begin{array}{l}\text { (+) } 64 \% \text { of the population confirmed that } \\
\text { CFs have improved community } \\
\text { participation in forest management. }\end{array}$ & $\begin{array}{l}\text { Bakingili, Woteva, and Bimbia- } \\
\text { Bonadikombo (Ngang 2015) }\end{array}$ & $\begin{array}{l}\text { Small and closely knit nature of Bakingili and Woteva CFs } \\
\text { facilitated community mobilization and information sharing. The } \\
\text { "big upside" phenomenon in Bakingili was community member } \\
\text { assembly at the chief's palace to discuss village and CF matters, } \\
\text { encouraging equal participation. }\end{array}$ \\
\hline $\begin{array}{l}(+) \text { Improved awareness of environmental } \\
\text { protection and sustainable exploitation } \\
\text { practices. }\end{array}$ & $\begin{array}{l}\text { Bakingili, Woteva, and Bimbia- } \\
\text { Bonadikombo (Ngang 2015) }\end{array}$ & $\begin{array}{l}\text { Technical support through sensitizations, trainings, field } \\
\text { demonstrations by Ministry of Forest and Fauna through the } \\
\text { program for sustainable management of natural resources, } \\
\text { nongovernmental organizations (NGOs), and community } \\
\text { organizations. }\end{array}$ \\
\hline $\begin{array}{l}(+) \text { Fair representation of the Baka in the } \\
\text { management committee. }\end{array}$ & $\begin{array}{l}\text { Moangue CF, east region (Assembe } \\
\text { 2006) }\end{array}$ & $\begin{array}{l}\text { This was principally because of technical support and the fact } \\
\text { that the majority of the population of the village was from the } \\
\text { Baka ethnic group. }\end{array}$ \\
\hline $\begin{array}{l}\text { (+) Empowerment of local communities led } \\
\text { to the creation of a CF by the Pygmy. }\end{array}$ & $\begin{array}{l}\text { Moangue-le-Bosquet CF, east region } \\
\text { (Etoungou 2003) }\end{array}$ & Technical support and training. \\
\hline $\begin{array}{l}(+) \text { CF employment increased because of } \\
\text { timber exploitation. }\end{array}$ & $\begin{array}{l}\text { Kongo CF, east region (Cuny et al. } \\
\text { 2007) }\end{array}$ & $\begin{array}{l}\text { Technical and financial support from the SNV Netherlands } \\
\text { Development Organization Support to Sustainable Development } \\
\text { in the Lomié/Dja region project. }\end{array}$ \\
\hline $\begin{array}{l}\text { (+) Contribution to social investment like } \\
\text { roofing for housing, provision of water, } \\
\text { health, and training. }\end{array}$ & $\begin{array}{l}\text { Gbopaba CF, east region (Mbile et al. } \\
\text { 2009) }\end{array}$ & $\begin{array}{l}\text { Technical and financial support from NGOs coupled with } \\
\text { income generation and strong community participation. }\end{array}$ \\
\hline $\begin{array}{l}(+) 66 \% \text { of CFs studied were slightly better } \\
\text { off than no-CF scenario ecologically and } \\
\text { economically. }\end{array}$ & $\begin{array}{l}\text { Southwest, south, east, center, and } \\
\text { littoral regions (Ingram et al. 2010) }\end{array}$ & $\begin{array}{l}\text { Access right and choice of } \mathrm{CF} \text { activities coupled with technical } \\
\text { support to improvement of } \mathrm{CF} \text { scenario. }\end{array}$ \\
\hline
\end{tabular}

Source: Authors' compilation.

instrumental in moving CFs forward are recognized nationwide. In the same vein, it might be helpful for MINFOF to actively pursue elites that are allegedly involved in CF-related corruption. Little evidence exists of communities successfully prosecuting corrupt individuals in community forestry in Cameroon and of any form of recognition of hardworking and supportive elites, but these are potentially helpful instruments if well implemented.

\section{CONCLUSION AND RECOMMENDATIONS}

We set out to evaluate within-community good governance through 6 principles: participation, accountability, equity, representation, direction, and performance. Evidence from 36 case studies suggests mixed results. The majority of the cases recorded negative outcomes as has been the case in the wider community forestry governance literature. We chose to further discuss and examine the conditions and drivers of positive outcomes recorded, mostly in the domains of participation and voice, representation, direction, and performance, in a bid to propose incentives that could help enhance good governance within community forestry. The specific positive outcomes included improved community participation in sustainable management of the forest, improved awareness of environmental protection, and sustainable exploitation practices. Fair representation of the Baka in management committees and empowerment of local communities led to the creation of a $\mathrm{CF}$ by the Pygmy, increased employment in CFs, and increased contribution to social investments like roofing for housing, provision of water, health, and training. The main drivers of positive outcomes were identified to include mainly capacity building, technical and financial support, choice, and availability of income-generating activities. These factors correspond to success factors identified in developing countries such as capacity building, social cohesion, and participation (Baynes et al. 2015) and Cameroon-specific success factors such as benefit generation, partnership, monitoring policy support, technical support, governance, financial support, practice choices, and institutions (Duguma et al. 2018).

Based on the literature on incentives, we suggest the following incentives corresponding to each of the key drivers:

1. To enhance economic activities, promote rural and community forest enterprises through soft loans and costsharing schemes for the acquisition of heavy capital equipment. Facilitate processes of obtaining CFE legal documents such as waybills and certificates of origin, and explore potentially concerted partnership between MINFI and MINFOF to eliminate taxes on products from CFEs because of their status as social enterprises.

2. Enhance technical support through concerted efforts between government agencies such as MINFI and MINFOF, technical support in value chain development, and access to markets through MINPMESSA. Other development partners and advocates of community forestry can organize national workshops in collaboration with national agencies to discuss and agree on techniques of addressing recurrent $\mathrm{CF}$ governance challenges such as elite capture, gender and minority inequality, poor accountability, and participation. Such national workshops will equally serve as avenues to review current legal regulatory text to integrate $\mathrm{CF}$ governance-related issues relative to representation, accountability, and equity. Official recognition of civil society organizations during such workshops that have significantly contributed to improving 
CF management and governance through capacity building would be a significant moral boost to these organizations.

3. Encourage supportive elites through incentives such as awards. The community forestry network and the subdirectorate of community forestry in MINFOF could institute recognition and an award-type approach to CFs on a periodic basis, in which the elites that support and are instrumental in moving CFs forward are recognized nationwide. Second, enforcing disincentives that would apply in instances of negative outcomes such as naming and shaming and punishment/prosecutions in cases of corruption or embezzlement and power abuse by elites would serve as deterrents.

These incentives, when actively considered in future policies, could potentially help enhance and stimulate good governance within community forestry with appropriate implementation.

[1] These are incentives that are delivered through lecturing or demonstrations.

Responses to this article can be read online at: http://www.ecologyandsociety.org/issues/responses. php/10330

\section{Acknowledgments:}

The authors give special thanks to the World Agroforestry Centre (ICRAF) team and DFID for financing the Dryad Project.

\section{LITERATURE CITED}

Alemagi, D. 2011. Sustainable development in Cameroon's forestry sector: progress, challenges, and strategies for improvement. African Journal of Environmental Science and Technology 5:65-72.

Assembe, S. 2004. Décentralisation des ressources forestières et justice environnementale: Analyse des évidences empiriques du SudCameroun. Dissertation pour le Diplôme de Droit International de l'Environnement (non publiée). United Nations Institute of Training and Research, Geneva, Switzerland.

Assembe, S. 2006. Forestry income management and poverty reduction: empirical findings from Kongo, Cameroon. Development in Practice 61:67-72.

Bakharia, A. 2014. Interactive content analysis: evaluating interactive variants of non-negative matrix factorisation and latent Dirichlet allocation as qualitative content analysis aids. Dissertation. Queensland University of Technology, Brisbane, Queensland, Australia.

Bakouma, J., and J. Sève. 2012. Forest management by community forest enterprises. Private Sector \& Development 14:13-15. [online] URL: https://www.cesbc.org/developpement_durable/textes/ jbakouma jseve eng.pdf

Barsimantov, J. A. 2010. Vicious and virtuous cycles and the role of external non-government actors in community forestry in Oaxaca and Michoachán, Mexico. Human Ecology 38:49-63. http://dx.doi.org/10.1007/s10745-009-9289-3
Barsimantov, J., and J. N. Antezana. 2012. Forest cover change and land tenure change in Mexico's avocado region: is community forestry related to reduce deforestation for high-value crops? Applied Geography 32:844-853. http://dx.doi.org/10.1016/j. apgeog.2011.09.001

Baynes, J., J. Herbohn, C. Smith, R. Fisher, and D. Bray. 2015. Key factors which influence the success of community forestry in developing countries. Global Environmental Change 35:226-238. http://dx.doi.org/10.1016/j.gloenvcha.2015.09.011

Beauchamp, E., and V. Ingram. 2011. Impacts of community forests on livelihoods in Cameroon: lessons from two case studies. International Forestry Review 13:389-403. http://dx.doi. org/10.1505/146554811798811371

Bigombé L. 2007. Les Régimes de Tenure Forestière et leurs Incidences sur la Gestion des Forêts et la Lutte contre la Pauvreté au Cameroun. Technical report. Food and Agricultural Organization of the United Nations, Rome, Italy.

Bodin, Ô., and B. I. Crona. 2008. Management of natural resources at the community level: exploring the role of social capital and leadership in a rural fishing community. World Development 36:2763-2779. http://dx.doi.org/10.1016/j. worlddev.2007.12.002

Brown, H. C. P., and J. P. Lassoie. 2010. Institutional choice and local legitimacy in community-based forest management: lessons from Cameroon. Environmental Conservation 37:261-269. http:// dx.doi.org/10.1017/S0376892910000603

Calderon, M., and A. A. Nawir. 2006. An evaluation of the feasibility and benefits of forest partnerships to develop tree plantations: case studies in the Philippines. Centre for International Forestry Research (CIFOR) Working Paper No. 27. CIFOR, Bogor, Indonesia.

Casey, F., S. Vikemann, C. Hummon, and B. Taylor. 2006. Incentives for biodiversity conservation: an ecological and economic assessment. Defenders of Wildlife, Washington, D.C., USA. [online] URL: https://defenders.org/publications/ incentives for biodiversity conservation.pdf

Chhetri, B. B. K., F. H. Johnsen, M. Konoshima, and A. Yoshimoto. 2013. Community forestry in the hills of Nepal: determinants of user participation in forest management. Forest Policy and Economics 30:6-13. http://dx.doi.org/10.1016/j. forpol.2013.01.010

Colfer, C. J. P. 2011. Marginalized forest people's perceptions of the legitimacy of governance: an exploration. World Development 39:2147-2164. http://dx.doi.org/10.1016/j.worlddev.2011.04.012

Cuny, P. 2011. Etat des lieux de la foresterie communautaire et communale au Cameroun. Tropenbos International Programme $\mathrm{du}$ bassin du Congo, Wageningen, Pays-Bas, the Netherlands.

Cuny, P., A. A. Ango, and Z. A. Ondoa. 2007. Local and decentralized forest management in Cameroon: the case of the Kongo community forest. In Oberndorf, R., P. Durst, S. Mahanty, K. Burslem, and R. Suzuki, editors. A cut for the poor. Proceedings of the International Conference on Managing Forests for Poverty Reduction: capturing opportunities in forest harvesting and wood processing for the benefit of the poor (Ho Chi Minh City, Vietnam, 3-6 October 2006). Food and Agriculture Organization of the 
United Nations (FAO) Regional Office for Asia and the Pacific Publication 2007/09 and Regional Community Forestry Training Center for Asia and the Pacific (RECOFTC) Report No. 19. FAO and RECOFTC, Bangkok, Thailand. [online] URL: http://www. fao.org/docrep/010/ag131e/ag131e09.htm

Dressler, W., B. Büscher, M. Schoon, D. Brockington, T. Hayes, C. A. Kull, J. McCarthy, and K. Shrestha. 2010. From hope to crisis and back again? A critical history of the global CBNRM narrative. Environmental Conservation 37:5-15. http://dx.doi. org/10.1017/S0376892910000044

Duguma, L. A., P. A. Minang, D. Foundjem-Tita, P. Makui, and S. Mandiefe Piabuo. 2018. Prioritizing enablers for effective community forestry in Cameroon. Ecology and Society 23(3):1. https://doi.org/10.5751/ES-10242-230301

Eben, E. 2014. Sustainable management of Prunus africana on Mount Cameroon. The South West Regional Delegate for the Ministry of Forestry and Wildlife, Buea, Cameroon.

Eloundou, K. 2012. Décentralisation forestière et gouvernance locale des forêts au Cameroun : le cas des forêts communales et communautaires dans la région Est. Dissertation. Géographie, Université du Maine, Les Mans, France.

Etoungou, P. 2003. Decentralization viewed from inside. The implementation of community forests in East-Cameroon. Working Paper 12, Environmental Governance in Africa Series. The World Resource Institute, Washington, D.C., USA.

Ezzine de Blas, D., M. R. Pérez, J. A. Sayer, G. Lescuyer, R. Nasi, and A. Karsenty. 2009. External influences on and conditions for community logging management in Cameroon. World Development 37:445-456. http://dx.doi.org/10.1016/j.worlddev.2008.03.011

Fisher, R. J. 2014. Lessons learned from community forestry in Asia and their relevance for REDD+: Forest Carbon, Markets and Communities (FCMC) Program. USAID, Washington, D.C., USA.

Fondufe, S., J. K. Ndzifon, and S. G. Akhere. 2016. Strengthening women's participation in the sustainable management of the Bimbia Bonadikombo Community Forest of Cameroon: challenges and blueprints. International Journal of Sustainable Development Research 2:12-17.

Food and Agricultural Organization of the United Nations (FAO). 1978. Forestry for local community development. Forestry Paper 7. FAO, Rome, Italy.

Gentle, P., K. P. Acharya, and G. R. Dahal. 2007. Advocacy campaign to improve governance in community forestry: a case from western Nepal. Journal of Forest and Livelihood 6:59-69.

Gurung, A., R. Bista, R. Karki, S. Shrestha, D. Uprety, and S.E. Oh. 2013. Community-based forest management and its role in improving forest conditions in Nepal. Small-scale Forestry 12:377-388. http://dx.doi.org/10.1007/s11842-012-9217-z

Hayes, T., and L. Persha. 2010. Nesting local forestry initiatives: revisiting community forest management in a REDD+ world. Forest Policy and Economics 12:545-553. http://dx.doi. org/10.1016/j.forpol.2010.07.003
Heimlich, R. E., K. D. Wiebe, R. Claassen, D. Gadsby, and R. M. House. 1998. Wetlands and agriculture: private interests and public benefits. Agricultural Economic Report No. 765. Resource Economics Division, Economic Research Service, U.S. Department of Agriculture, Washington, D.C., USA.

Ingram, V., E. Beauchamp, G. Lescuyer, M. Parren, C. Njomgang, and A. Awono. 2010. Costs, benefits and impacts of community forests on livelihoods in Cameroon. In Taking stock of smallholder and community forestry: where do we go from here? (Montpellier, France, 24-26 March 2010). Centre for International Forestry Research, Bogor, Indonesia.

Karsenty, A., and C. Vermeulen. 2016. Towards concessions 2.0 in Central Africa. Managing overlapping rights between industrial concessions and community forestry. Perspective No. 38. CIRAD, Montpellier, France.

Kayambazinthu, D., F. Matose, G. C. Kajembe, and N. Nemarundwe. 2003. Institutional arrangements governing natural resource management of the Miombo woodland. Pages 45-79 in G. Kowero, B. M. Campbell, and U. R. Sumaila, editors. Policies and governance structures in woodlands of southern Africa. Centre for International Forestry Research, Bogor, Indonesia.

Lamichhane, D., and R. Parajuli. 2014. How good is the governance status in community forestry? A case study from midhills in Nepal. Journal of Ecosystems 2014:541374. http://dx. doi.org/10.1155/2014/541374

Le H. D., C. Smith, J. Herbohn, and S. Harisson. 2012. More than just trees: assessing reforestation success in tropical developing countries. Journal of Rural Studies 28:5-19. http://dx.doi. org/10.1016/j.jrurstud.2011.07.006

Maffo, H. N. N., and A. Bokkestijn. 2015. Implementation of forest law enforcement, governance and trade in Cameroon: performance analysis of community forest. In XIV World Forestry Congress (Durban, South Africa, 7-11 September 2015). Food and Agriculture Organization of the United Nations, Rome, Italy.

Maidell, M., E. Cheney, and E. Rametsteiner. 2012. A common framework to assess and monitor forest governance. ETFRN, moving forward with forest governance. ETFRN News 53:55-63.

Malla, Y., R. Barnes, K. Paudel, A. Lawrence, H. Ojha, and K. Green. 2002. Common property forest resource management in Nepal: developing monitoring systems for use at the local level. International and Rural Development Department, University of Reading, Reading, United Kingdom.

Mbile, P., G. Ndzomo-Abanda, H. Essoumba, and A. Misouma. 2009. Alternate tenure and enterprise models in Cameroon: community forests in the context of community rights and forest landscapes. World Agroforestry Centre and Rights and Resources Initiative, Washington, D.C., USA.

Minang, P. A. 2018. Values, incentives and ecosystem services in environmentalism. In S. Lele, E. Brondizio, J. Byrne, G. M. Mace, and J. Martinez-Alier, editors. Rethinking environmentalism: linking justice, sustainability, and diversity. Strüngmann Forum Reports, Volume 23. MIT Press, Cambridge, Massachusetts, USA, in press. 
Minang, P. A., M. K. McCall, and H. Th. A. Bressers. 2007. Community capacity for implementing clean development mechanism projects within community forests in Cameroon. Environmental Management 39:615-630. http://dx.doi.org/10.1007/ $\underline{\text { s00267-005-0275-2 }}$

Ministry of Environment and Forests (MINEF). 1998. Manual of the procedures for the attribution and norms for the management of community forests in Cameroon. MINEF, Yaoundé, Cameroon.

Ministry of Forest and Fauna (MINFOF). 2009. Manual of the procedures for the attribution, and norms for the management of community forests in Cameroon. Revised version. MINOF, Yaoundé, Cameroon.

Monsi, J. N. 2014. Communites' role in sustainable forest management in Cameroon: managers or participants? Thesis. Ritsumeikan Asia Pacific University, Beppu, Ōita Prefecture, Japan.

Ngang, D. F. 2015 Contribution of community based natural resource management to livelihoods, conservation and governance in Cameroon. A comparative assessment of three community forests in Fako. Thesis. Pan African Institute for Development-West Africa, Buea, Cameroon.

Nkemnyi, M. F., T. De Herdt, G. B. Chuyong, and T. Vanwing. 2016. Reconstituting the role of indigenous structures in protected forest management in Cameroon. Forest Policy and Economics 67:45-51. http://dx.doi.org/10.1016/j.forpol.2016.03.012

Nkenfack H., C. Njomgang, and D. Sharpe. 2009. An approach for the evaluation of rural governance in Cameroon: are community forests really forests for the communities? Annals of "Dunarea de Jos" University of Galati, Fascicle I: Economics and Applied Informatics 2:85-100.

Nuesiri, E. O. 2016, Decentralised forest management: towards a utopian realism. Geographical Journal 182:97-103. http://dx.doi. org/10.1111/geoj.12104

Ojha, H., and K. Kanel. 2005. 25 Years of community forestry in Nepal: a review of Fourth National Workshop Proceeding. Journal of Forest and Livelihood 4:56-60.

Oyono, P. R. 2003. Institutional deficit, representation and decentralized forest management in Cameroon. Elements of natural resource sociology for social theory and public policy. Working Paper 15, Environmental Governance in Africa Series, The World Resource Institute, Washington, D.C., USA.

Oyono, P. R. 2004. One step forward, two steps back? Paradoxes of natural resources management decentralization in Cameroon. Journal of Modern African Studies 42:91-111. http://dx.doi. org/10.1017/S0022278X03004488

Oyono, P. R. 2005. Profiling local-level outcomes of environmental decentralizations: the case of Cameroon's forests in the Congo Basin. Journal of Environment and Development 14:317-337. http://dx.doi.org/10.1177/1070496505276552

Oyono, P. R. 2007. Understanding forest tenure in Central Africa: transitions or hidden status quo at the dawn of the new century. Rights and Resources Initiative, International Union for Conservation of Nature, Washington, D.C., USA.
Oyono, P. R., M. B. Biyong, and S. K. Samba. 2012. Beyond the decade of policy and community euphoria: the state of livelihoods under new local rights to forest in rural Cameroon. Conservation and Society 10:173-181. http://dx.doi.org/10.4103/0972-4923.97489

Oyono, P. R., and S. Efoua. 2006. Qui représente qui? Choix organisationnels, identités Sociales et formation d'une élite forestière au Cameroun. Africa Development 31:147-182.

Program on Forests (PROFOR) and Food and Agriculture Organization of the United Nations (FAO). 2011. Framework for assessing and monitoring forest governance. FAO, Rome, Italy. [online] URL: http://www.fao.org/climatechange/27526-0cc61ecc084048c7a9425f64942df70a8.pdf

Pye-Smith, C. 2010. Cameroon's hidden harvest. Center for International Forestry Research, Bogor, Indonesia.

Sitoe, A. A., and B. S. Guedes. 2015. Community forestry incentives and challenges in Mozambique. Forests 6:4558-4572. http://dx.doi.org/10.3390/f6124388

Smith, P. D., K. C. Bur-Bahadur, and R. Bimal. 2003. Meeting the needs of Nepal's poor: creating local criteria and indicators of community forestry. Journal of Forestry 101:24-30.

Tieguhong, J. C. 2016. Report on public-private partnerships $(P P P)$ in the forestry sector in Cameroon. African Forest Forum, Nairobi, Kenya.

Tiwari, S. 2002. Access, exclusion \& equity issues in community management forests: an analysis of status of CFs in mid-hills of Nepal. Winrock International, Kathmandu, Nepal.

Tobith, C., and P. Cuny. 2006. Genre et foresterie communautaire au Cameroun. Quelles perspectives pour les femmes? Bois et Forêts des Tropiques 289:17-26.

Totikidis, V., A. Armstrong, and R. Francis. 2005. Local safety committees and the community governance of crime prevention and community safety. In Beyond Fragmented Government: Governance in the Public Sector Conference (Victoria University, Melbourne, 15-17 August 2005). Centre for International Corporate Governance Research (CICGR), Faculty of Business and Law, Victoria University, Melbourne, Victoria, Australia.

United Nations Development Programme (UNDP). 2004. Sources for democratic governance indicators. UNDP, Oslo, Norway.

United Nations Economic and Social Commission for Asia and the Pacific (UNESCAP). 2006. What is good governance? UNESCAP, Bangkok, Thailand. [online] URL: http://www. unescap.org/sites/default/files/good-governance.pdf 